\title{
NEW PHARMACEUTICAL DOSAGE FORMS USED IN THE TREATMENT OF BREAST CANCER. POLYMERIC MICELLES
}

Alexandu Oprita ${ }^{1}$, Ani-Simona Sevastre ${ }^{2^{*}}$

\begin{abstract}
Among all types of cancer encountered in women, breast cancer is the most prevalent, with the highest mortality rate. An increased survival rate is closely related to early diagnosis, the use of high performing screening methods and of selective and adequate treatments.

By using the nanotechnologies, the therapeutic effectiveness of the drugs may be improved by a controlled release of the active substances to the tumoral site. The aim of this review is to present the current state of knowledge and to mention the new treatment trends in breast cancer, focusing on a pharmaceutical form that, thanks to its advantages, is already used in the therapy of this disease - the polymeric micelles.

Several examples of anticancer agents loaded polymeric micelles are mentioned, illustrating the preparation methods and the current state of clinical studies in which polymeric micelles are used.
\end{abstract}

Keywords: breast cancer, pharmaceutical dosage form, nanomedicines, polymeric micelles

1 University of Medicine and Pharmacy of Craiova, Faculty of Medicine, Romania

2 University of Medicine and Pharmacy of Craiova, Faculty of Pharmacy, Romania

*Corresponding author: Ani-Simona Sevastre (anifetea_umf@yahoo.com)

Published online: 2 September 2020

\section{Introduction}

Among all types of cancer, breast cancer is the most prevalent in women, representing the highest mortality rate(1).

Depending on the histological characteristics, breast cancer is classified in $\mathrm{HR}+$ (hormone-receptor-positive), HER2+ (human epidermal growth factor receptor-2 overexpressing) and TNBC (triple-negative) breast cancer (2). For the metastatic breast cancer, endocrine therapy represents a mainstay treatment (3), that involve the use of SERMs (selective estrogen receptor modulators), SERDs (selective estrogen receptor downregulators) and Als (aromatase inhibitors) (4).

Lung, breast and colorectal are the most frequent diagnosed cancers worldwide. There are 4.4 million survivors up to 5 years following breast cancer diagnosis $(5$, 6). Breast cancer's exact etiology is not known, but some associated risk factors were observed, such as: family history of breast cancer (7), aging (8), obesity (9), nutrition (10), low physical activity (11), gene alteration (12), use of oral hormone replacement therapy and 
contraceptives(13) and chest radiation (14). Genetic mutations involve: high/low penetrance genes (BRCA1, BRCA2, p53, ATM, NBS1, PTEN, LKB1, respectively: CYP1A1, CYP2D6, CYP19), glutathione Stransferase genes (GSTM1, GSTP1), alcohol and 1C metabolism genes (ADH1C, MTHFR), DNA repair genes (XRCC1, XRCC3, ERCC4/XPF), cell signaling genes (PR, ER, TNF-alpha, HSP70) (15). Furthermore, HER-2/neu antigen was found to be overexpressed not only in breast cancer, but also in gastric, ovarian, oral and lung cancers (16).

There are several criteria that are used to categorize this disease. Considering the histogenetic characteristics and the DNA microarrays, the subtypes of breast cancer are presented in the figure 1.
In the past century, many diagnostic methods have been developed for cancer in general, and breast cancer in particular: mammography, magnetic resonance imaging (MRI), breast biopsy, HER-2/neu detection assay (immunohistochemistry, FISH test), Blood-based assay (CA 15-3, carcinoembryonic antigen CEA, CA 27-29, proteins, cancer cells, DNA/RNA, autoantibodies, genomics/proteomics) (19).

Although MRI has a low selectivity, breast cancer may be discovered in an early stage due to its high sensitivity. However, side effects and drawbacks may appear because of the use of contrast agents. Furthermore, new drug-delivery carriers such as nanosized formulations are recently used for the delivery of contrast agents to the tumor site (20).

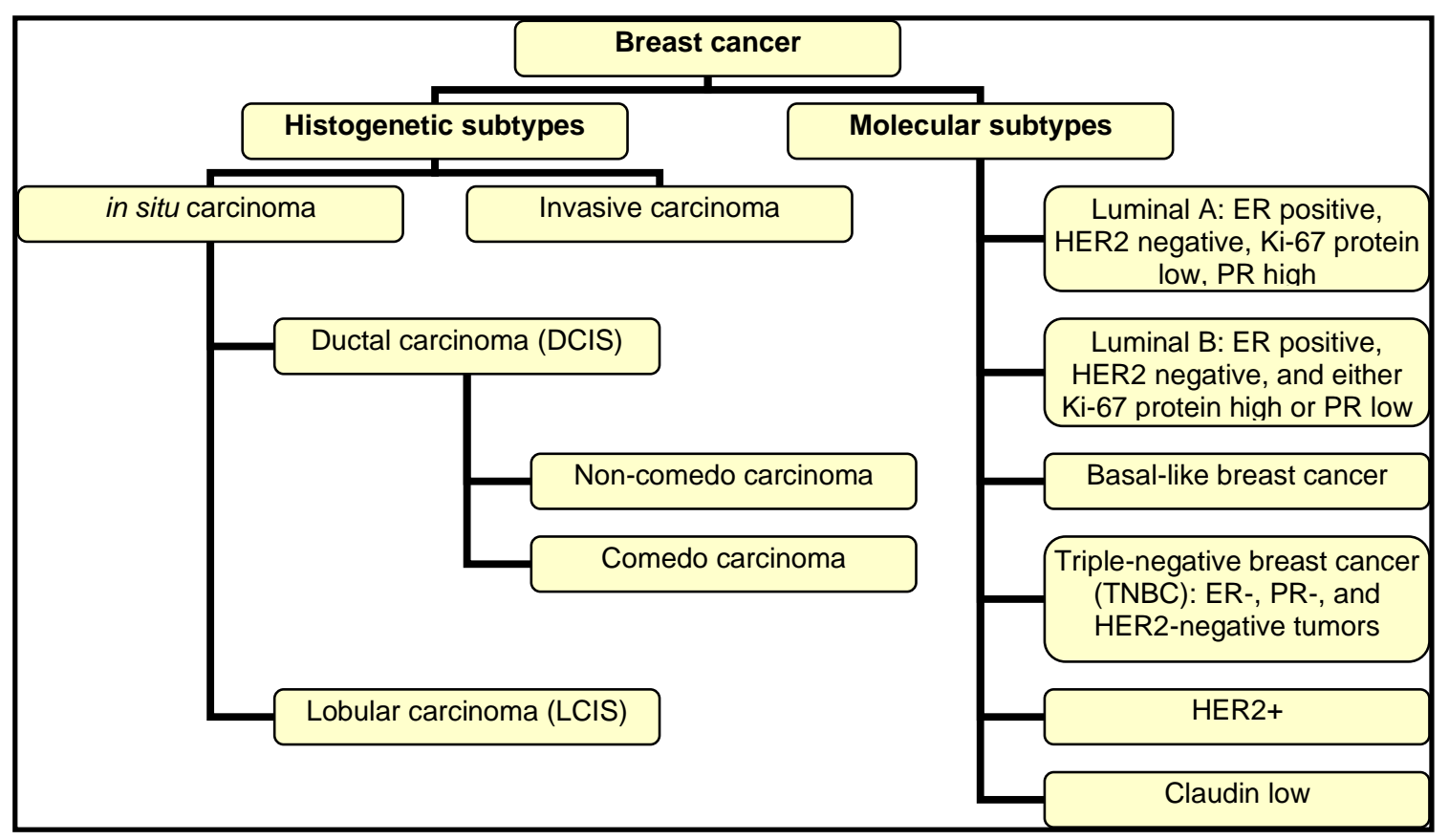

Figure 1 Breast cancer classes $(17,18)$ 
Nanomedicine is in continuous development, with many applications both in the clinical and nonclinical field. Taking into account the significant side effects and the high toxicity of anti-tumor treatments, it is easy to understand that the use of drugs that act directly on the target is a very important aspect. By using the nanotechnologies, the therapeutic effectiveness of the drugs may be improved by a controlled release of the active substances to the tumoral site (21).

Compared to conventional dosage forms, nanomedicines have particular characteristics that allow them to provide augmented safety, bioavailability and specificity. Their physicochemical properties may lead to changes in pharmacokinetics (absorption, distribution, elimination, metabolism) (22), with an increased potential to cross more easily biological barriers and a higer persistence in the body $(23,24)$. By the year 2013, from 11 commercially available nanomedications, EMA has approved 8, and 3 were withdrawn. Other nanomedicine products are in preclinical trials(25). By the year 2016, the FDA allready approved 51 nanomedicines, which can be classified in:

- polymer based nanomedicines (e.g. Paxone $\AA$, Ulasta $\AA$, and PLEGRIDY®),

- hydrophilic polymers (e.g. Venofer $\AA$, Ferrlecit $\AA$, Dexferrum $\AA$, Feraheme $\left.{ }^{\circledR}\right)$,

- liposomes (e.g. Onivyde®, Doxil®, Visudyne $\AA$, Thermodox $\AA)$,
- micelles(e.g. Estrasorb®, BIND014, CALAA-01),

- nanocrystals (e.g. Rapamune®, Tricor ${ }^{\circledR}$, Emend( ${ }^{\circledR}$, Megace ES $\AA$ ),

- antibody-drug conjugates (e.g. Brentuximab emtasine, Tratuzumab),

- $\quad$ proteic and inorganic nanoparticles (e.g. Abraxane®, Ontak®) (26).

Before FDA aproval, the properties of nano-formulation must be evaluated: physicochemical properties, formulations aspects, pharmacokinetics, distribution to blood and tissues, metabolism, elimination, accumulation in target tissues, elimination, toxicity (27).

Two major limitations that imped the entry of novel nanomedicines into the pharmaceutical market is the high cost and the fact that most of the reagents and inactive substances used in the formulation are not included in the FDA approved database of inactive ingredients (28).

\section{Conventional and novel therapies for breast cancer}

Early stage of breast cancer is considered to be potentially curable. In the past years, breast cancer therapy has substantially progressed and new therapies are emerging (29). In order to establish proper therapy concepts, a multidisciplinary setting is needed, focusing on the molecular subtype and locoregional tumour load (30). 
The main types of breast cancer treatment are: surgery, RT (radiation therapy), CT (chemotherapy), ET (endocrine therapy), and targeted therapy (31).

For the localized breast cancer, the first step is neoadjuvant therapy, in order to shrink tumor bulk, then the trending approach is surgery, usually followed by an adequate adjuvant therapy to minimize the apparition of metastases and to ensure full recovery.

To reduce the local recurrence of cancer, radiation therapy may be performed (31).
At the base of the selection of systemic adjuvant therapies is the surrogate intrinsic phenotype determined by HER-2, ER/PR and Ki-67 assessment (Figure 2):

- ET for endocrine-responsive histology (tubular, cribriform, and mucinous);

- CT for endocrine-nonresponsive (medullary, adenoid cystic, apocrine, and metaplastic)(32).

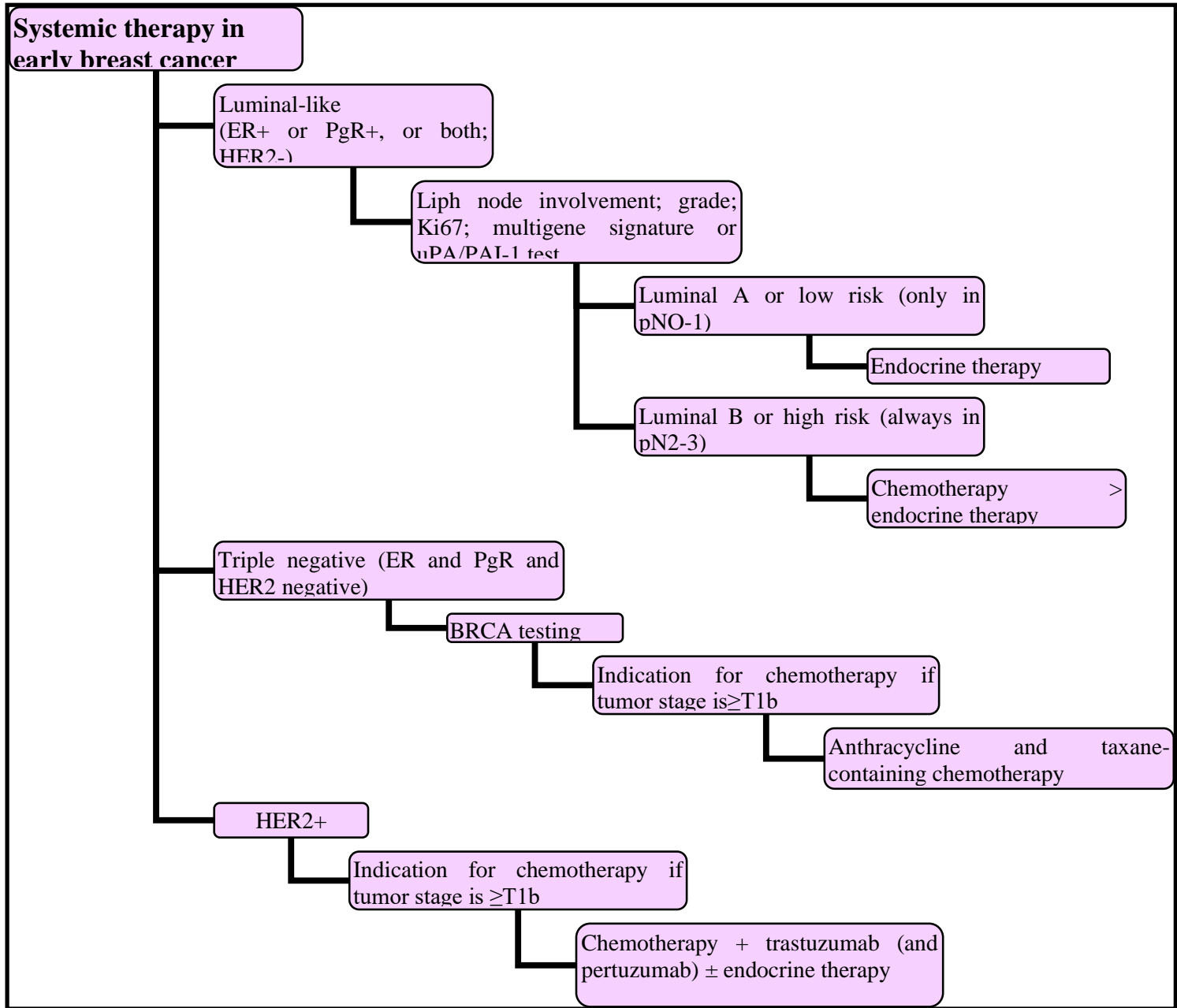

Figure 2 Principles of systemic therapy in early breast cancer (30) 


\begin{tabular}{|c|c|c|}
\hline \multirow{2}{*}{$\begin{array}{l}\text { LOCAL } \\
\text { TREATMENTS }\end{array}$} & \multicolumn{2}{|l|}{ Surgery } \\
\hline & \multicolumn{2}{|l|}{ Radiation } \\
\hline \multirow[t]{3}{*}{$\begin{array}{l}\text { SYSTEMIC } \\
\text { TREATMENTS }\end{array}$} & Chemotherapy & $\begin{array}{l}\text { - Anthracyclines: doxorubicin and epirubicin } \\
\text { - Taxanes: paclitaxel and docetaxel } \\
\text {-5-fluorouracil } \\
\text { - Cyclophosphamide } \\
\text { - Carboplatin } \\
\text { Advanced breast cancer: Taxanes and albumin-bound } \\
\text { paclitaxel, Anthracyclines, Platinum agents, } \\
\text { Vinorelbine, Capecitabine, Gemcitabine, Ixabepilone, } \\
\text { Eribulin } \\
\text { HER2+ cancers: drugs that target HER2 may be used } \\
\text { with chemotherapy. }\end{array}$ \\
\hline & $\begin{array}{l}\text { Hormone } \\
\text { Therapy }\end{array}$ & $\begin{array}{l}\text { - Estrogen receptors blockers: Tamoxifen, Toremifene, } \\
\text { Fulvestrant } \\
\text { - Estrogen level modifiers: Aromatase inhibitors } \\
\text { (Letrozole, Anastrozole, Exemestane), Ovarian } \\
\text { suppression } \\
\text { - Other hormone therapy: Megestrol acetate, } \\
\text { Androgens, High doses of estrogen }\end{array}$ \\
\hline & $\begin{array}{l}\text { Targeted } \\
\text { therapy }\end{array}$ & $\begin{array}{l}\text {-HER2-positive breast cancer: Trastuzumab, } \\
\text { Pertuzumab, Ado-trastuzumab emtansine, Lapatinib, } \\
\text { Neratinib } \\
\text { - Hormone receptor-positive breast cancer: CDK4/6 } \\
\text { inhibitors (Palbociclib, Ribociclib, Abemaciclib), } \\
\text { Everolimus } \\
\text { - BRCA gene mutations: Olaparib, Talazoparib }\end{array}$ \\
\hline
\end{tabular}

Table 1 Current local and systemic treatments for breast cancer (33)

Because of the extended side effects and low bioavailability of the conventional antineoplastic drugs (Table 1), novel aproaches for breast cancer treatment were investigated in the past 15 years (Figure 3).
Nanotechnology comes with the advantage of a targeted delivery of the active substances (31). Furthermore, new active substances were discovered, due to the advances in molecular biology (34) and pharmacology $(29,35)$.

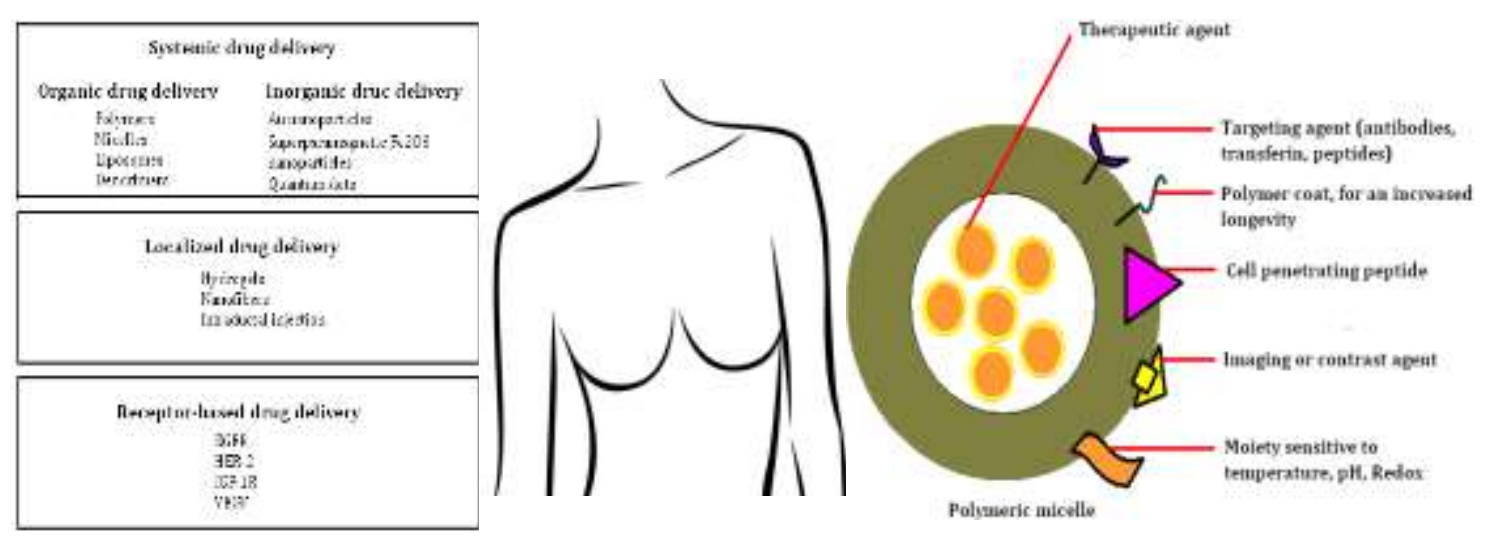

Figure 3 Drug delivery systems and different types of linkers used in breast cancer $(44,49)$ 
Passive targeting - The enhanced targeting may be passive or active. The cancer tissue's physical and chemical properties may represent good tools in the passive targeting (increased angiogenesis, slightly acidic $\mathrm{pH})(36)$.

Active targeting - A potential target is represented by an overexpression of antigens or receptors in cancers. For example, in 2017, alumina NPautophagosome conjugates were used to manage breast cancer (37).

\section{New active pharmaceutical entities and targeting moieties}

Thank to the newest discoveries in molecular biology, genetics, pharmacology, new generations of active and tailored active molecules are emerging for breast cancer management:

- human prolactin antagonistinterleukin 2 [hPRLA-IL-2]), a novel fusion protein acts as positive immunomodulator (38).

- tetrahydrocannabinol and phytocannabinoid cannabidiol have antiproliferative effect and inhibit id-1 gene expression in some breast cancers (39).

- gamma secretase inhibitor 1 (GSI1) inhibits the production of the substrate binding component (nicastrin, Nct) (40).

- retinamides inhibited the growth of established breast tumor xenografts blocking retinoic the acid metabolism via apoptosis (41).
- $\quad$ expression of human genes A7322 and F3374 (SEQ ID no: 79) is elevated in breast cancer (42).

Nanoparticles are new pharmaceutical forms used in the treatment of cancer in general and breast cancer in particular thanks to their capacity to encapsulate both hydrophilic and hydrophobic active substances and to their ability to be conjugated to various systems in order to provide a targeted therapy (43).

Systemic drug delivery approaches polymers, micelles, liposomes, dendrimers and nanogels (44).

Localized drug delivery approaches PEG, PLGA, chitosan, PLA, PVA, PCL or polyethylene oxide based nanofibers, chitosan hydrogels based on temperatureresponsive hydroxyl butyl, poly (vinyl alcohol), thermo sensitive poly (ethylene lycol)-grafted, chitosan chloride/glycerophosphate and chitosan/bifunctional aldehyde and intraductal injection (44).

PEG may be used to conjugate nanoparticles for a longer circulation time(45) Some polymers like polylactic-coglycolic acid (PLGA), that are used in NPs formulations, have high cell adhesion property (46). Beside all the advantages, nanoparticles may have many side effects such as: altered cellular redox balance and tissue inflammation, causing abnormalities in cell function, leading even to cell death (47). 
Receptor based drug delivery - HER-2, epidermal growth factor receptor [EGFR], vascular endothelial growth factor receptor [VEGFR], insulin-like growth factor I receptor [IGF-IR])-based targeting (44).

Depending on the materials they are synthesized of, NPs can be classified into: polymers (polimeric nanoparticles, micelles, dendrimers), lipids (liposomes), viruses (viral nanoparticles), organometallic compounds (nanotubes), metals colloids (Ag, $\mathrm{Au}$ ), metal oxides (TiO2, $\mathrm{SiO} 2)$, inorganic materials (carbon nanotubes, quantum dots, nanocrystals, nanoshells, nanowires, nanorods, nanopores, nanospheres, nanobelts, nanorongs, nanocaps, fullerenes) (48).

\section{Polymeric micelles}

Polymeric micelles are colloidal particles formed from amphiphilic block copolymers with a core-shell nanostructure. In aqueous media, the hydrophilic heads are arranged to outside and the hydrophobic tails to inside to stabilize the structure, structure that makes them suitable to deliver waterinsoluble chemotherapeutic drugs (50).

Methods of preparation of drug-loaded micelles

Usually, 3 approaches may be used to prepare drug-loaded micelles:

- DIRECT DISSOLUTION METHOD -

At a concentration $\geq \mathrm{CMC}$ (critical micelle concentration), the amphiphilic copolymer and the therapeutic agent self assemble to form the drug-loaded micelles. To increase the drug loading, high temperature or a thin drug film may be used.

- SOLVENT

EVAPORATION METHOD (SOLUTION CASTING METHOD) - The copolymer and the drug are dissolved in a volatile organic solvent. Then, the solvent is evaporated and removed, leading to a thin film of drug and copolymer. The micelles are formed when water is added over the film (51).

- DIALYSIS METHOD is very suitable for long and very hydrophobic copolymers. The organic solution of the polymer and drug is put in a dialysis bag, then the bag is immersed into water, exchanging the organic solvent with this second solvent, leading to micelle assembly. To shorten this method, a mixture of water/tert-butanol is used as solvent, afterwhich, this solution is lyophilized. The micelles are obtained after redispersion in a suitable vehicle (52) (Figure 4). Different polimers may be used as seen in Table 2. Di-blocks (A-B), triblocks (A-B-A) and graft co-polymers may be used to form micelles. 


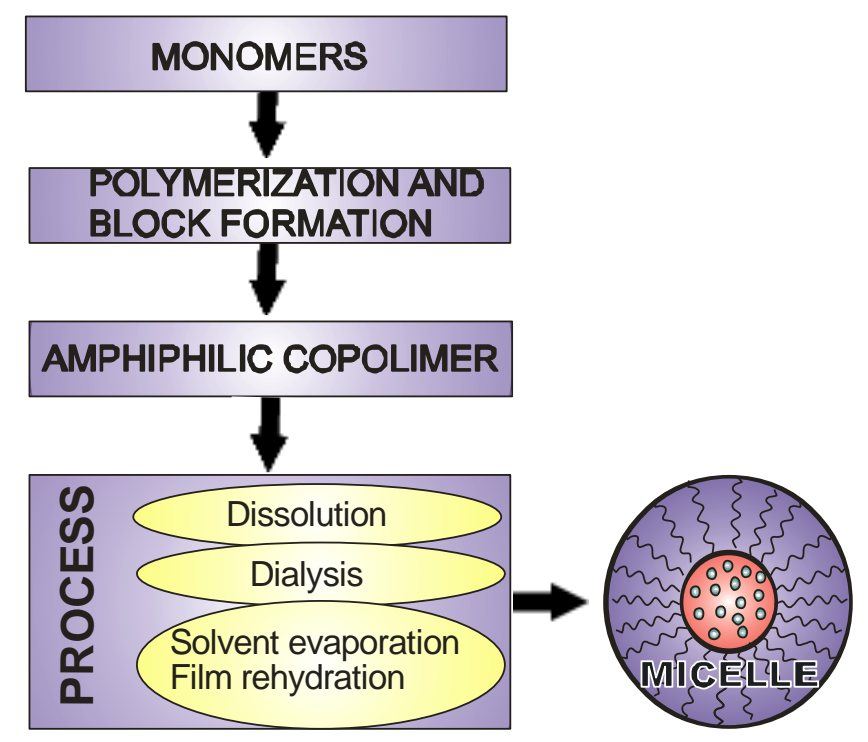

Figure 4 Micelle preparation steps (53)

\begin{tabular}{|c|c|c|}
\hline $\begin{array}{l}\text { POLYMER } \\
\text { CLASS }\end{array}$ & EXAMPLES & FEATURES \\
\hline $\begin{array}{l}\text { Chitosan } \\
\text { derivatives }\end{array}$ & $\begin{array}{l}\text { N-Phthaloylcarboxymethylchitosan } \\
\text { Oleoyl-carboxymethyl chitosan } \\
\text { N-palmitoyl chitosan }\end{array}$ & $\begin{array}{ll}\text { - Chitosan has } & \text { also } \\
\text { bacteriostatic } & \text { and } \\
\text { fungistatic action. } & \end{array}$ \\
\hline $\begin{array}{l}\text { Pyrolidone } \\
\text { derivatives }\end{array}$ & Poly(N-vinyl pyrrolidone) (PVP) & $\begin{array}{l}\text { - High water solubility, } \\
\text { and flexibility. }\end{array}$ \\
\hline Polyamides & Poly(Nisopropylacrylamide) (pNIPAAm) & $\begin{array}{l}\text { - It may be used to } \\
\text { prepare thermo-sensitive } \\
\text { polymeric micelles. }\end{array}$ \\
\hline \multirow[t]{2}{*}{ Polyethers } & 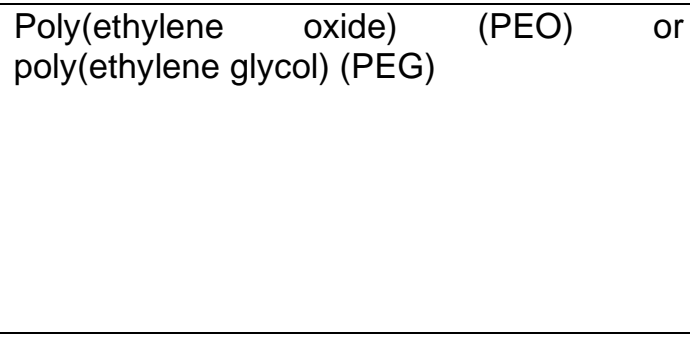 & $\begin{array}{l}\text { - The most utilized } \\
\text { hydrophilic block to coat } \\
\text { nanoparticles; } \\
\text { - Non-toxic, flexible, } \\
\text { hydrophilic, and electrically } \\
\text { neutral; } \\
\text { - PEG-coating prolongs } \\
\text { the circulation time. }\end{array}$ \\
\hline & Poly(propylene oxide) (PPO) & $\begin{array}{l}\text { - They are very dynamic } \\
\text { when assembled. }\end{array}$ \\
\hline Polyesters & $\begin{array}{l}\text { Poly(L-lactide) (PLA), poly- } \delta \text {-caprolactone } \\
\text { (PCL), poly(lactide-co-glycolic acid) } \\
\text { (PLGA), poly( } \beta \text {-aminoesters) }\end{array}$ & $\begin{array}{l}\text { - The block co-polymers } \\
\text { hydrolyse in the biological } \\
\text { system and are degraded } \\
\text { to non-toxic monomers. }\end{array}$ \\
\hline $\begin{array}{l}\text { Polyamino } \\
\text { acids }\end{array}$ & $\begin{array}{lll}\text { Poly(L-histidine) } & \text { (pHis), } & \text { poly(L-aspartic } \\
\text { acid) (pAsp) } & & \end{array}$ & $\begin{array}{l}\text { - They can transport } \\
\text { drugs by chemical } \\
\text { modifications (unlike other } \\
\text { classes of core-forming } \\
\text { polymers). }\end{array}$ \\
\hline Lipids & $\begin{array}{l}\text { Distearoyl(phosphatidylethanolamine) } \\
\text { (DSPE), } \\
\text { Dioleoyl(phosphatidylethanolamine) } \\
\text { (DOPE) }\end{array}$ & $\begin{array}{l}\text { • Excellent } \\
\text { biocompatibility } \\
\text { amphiphilicity. }\end{array}$ \\
\hline
\end{tabular}

Table 2 Example of polymers used for micelle preparation $(50,53-57)$ 
Micelles have special characteristics:

- The of size and morphology of amphiphilic block copolymer are easily controlled by an adequate selection of: molecular weight, aggregation number, proportion of hydrophilic/hydrophobic chains, volume of solvent inside the micellar core, preparation process.

- They may be sterilized by filtrative sterilization, due to their colloidal dimensions.

- The micellar core can entrap poorly water-soluble substances, overcoming solubility, incompatibility, instability problems (enhanced bioavailability)

- Compared to surfactant micelles, polymeric micelles are more stable when diluted, exhibiting minimal cytotoxicity.

- The polymeric micelles prevent mechanical clearance by renal filtration and reticuloendothelial system, prolonging the blood circulation of drug, with high rate of accumulation in low vascularized tumors (58). Increased intracellular drug concentration is achived by overcoming the P-gp efflux and by acting through receptor-mediated endocytosis $(59,60)$.

- The risk of embolism is minimized, due to nanoscopic size.

- $\quad$ Receptor-mediated targeted drug and gene delivery may benefit from polymeric micelles, which can be end- functionalizated with sugars and peptides.

- High binding specificity and targetability may be achieved by covalent bound of monoclonal antibody molecules (61).

- They may be stimuli-sensitive $(\mathrm{pH}$, temperature) $(53,62)$.

Recent implications of polymeric micelles in breast cancer

As promising drug-delivery nanocarrier, polymeric micelles attracted increasing attention in treating cancer in the last years (63) (Figure 5).

- The polymer of NIPAM-VP [poly(N-isopropylacrylamide)] was used to obtain micelles of Paclitaxel (NanoxeI) and several studies were conducted. In 2006, the Indian Drug Regulatory Authority approved its use in the indian pharmaceutical market as an alternative to Cremophor EL- paclitaxel (64).

- $\quad$ In 2008, Paclitaxel was entraped in mPEG-PDLLA: monomethoxy-poly (ethylene glycol)-block-poly(D,L-lactide) micelles (Genexol-PM) and after rigorous studies, it has been granted for FDA aproval for metastatic breast cancer $(65,66)$.

- In the same year, methoxycapped poly(ethylene glycol)-blockpoly( $\varepsilon$-caprolactone) (mPEG-b-PCL) micelles loaded with 17-allylamino-17demethoxy Geldanamycin were formulated. That study concluded that, 
even in the absence of ligands, the nanoscale dimensions may offer specificity of the drug, because of the EPR effect (67).

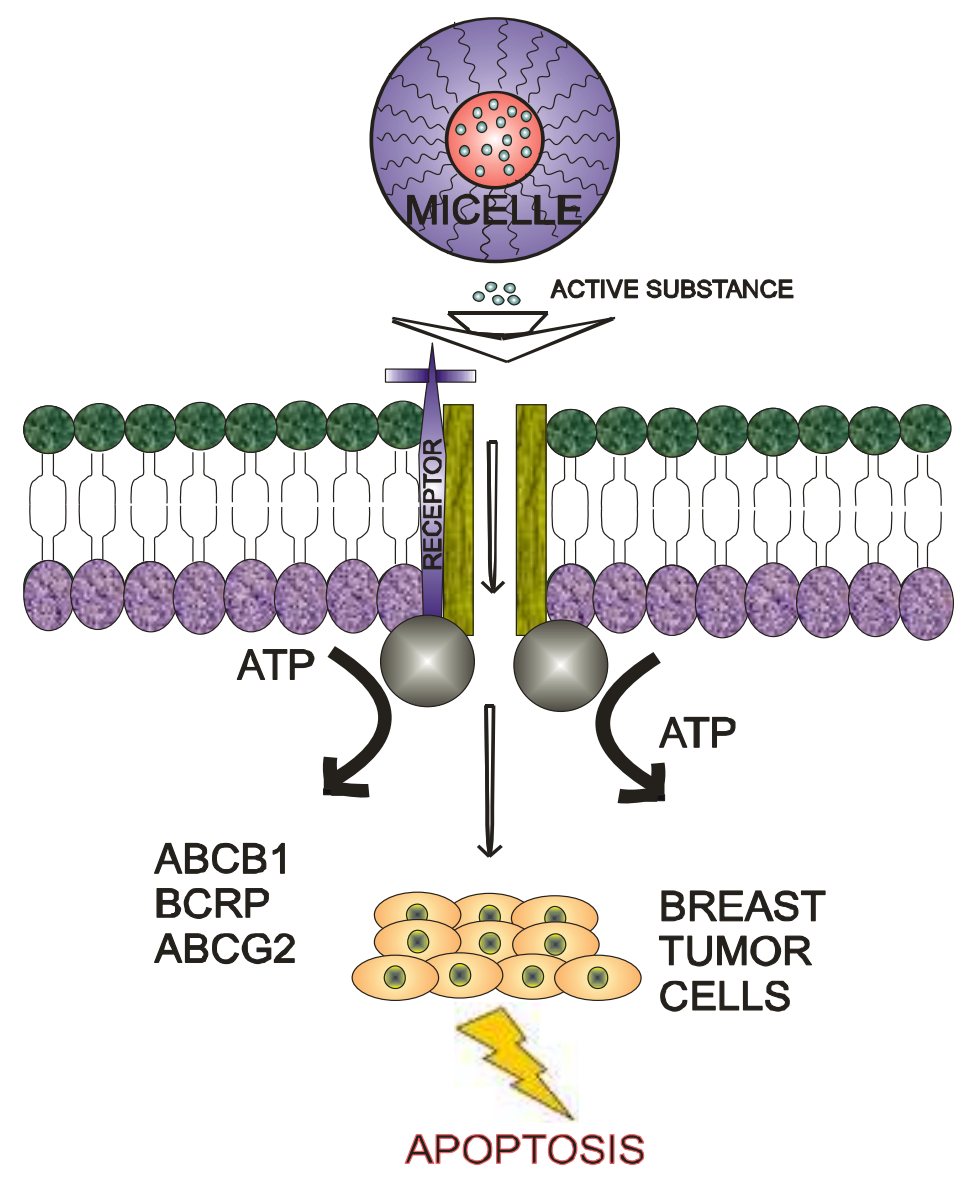

Figure 5 Polymeric micelles-based drug delivery mechanism in drug-resistant breast cancer cells (44)

- In november 2018, a multicenter phase IV study for breast bancer treatment started to evaluate Docetaxel polymeric micelles for safety, quality of life (QoL) and toxicity. The formulation was prepared using poly $(\mathrm{N}$ vinylpyrrolidone)-block-poly(D,L-lactide) (PVP-b-PDLLA). The docetaxel loaded polymeric micelles are expected to have improved solubility, reduced toxicity and hypersensitivity compared to the drug alone (68).
- Nippon Kayaku Co.,Ltd formulated Paclitaxel loaded PEG-PAA plymeric micelles (NK105) which are now in Phase 3 of clinical study for NOS metastatic recurrent breast cancer (69).

- Several studies used antibodybounded micelles to treat breast adenocarcinomas, by triggering immune response:

1. In 2009, Lee et al. used Paclitaxel loaded polymeric micelles conjugated with anti-HER-2 antibody. The complex shown high efficacy in 
HER-2-positive and HER-2-negative cells (70).

2. Anti-HER-2 monoclonal antibody (mAb) was conjugated with lysosomal P (LA-Co-TMCC)-g-PEG-furan micelles for the treatment of HER-2positive breast cancer (71).

3. Anti-HER2 antibody was conjugated with Docetaxel and pololike kinase 1 siRNA (siPIk1) loaded micelle nanoparticles composed of vitamin E d-a-tocopheryl polyethylene glycol succinate (TPGS) and TPGSsiRNA conjugates. The presence of receptor targeting antibody demonstrated higher toxicity compared to the nano-carriers that did not have an antibody against breast cancer cell (72).

4. For maximum therapeutic efficacy, intracellular localization must be reached. In 2012, Hoang et al. labeled the antibody, the peptide and the conjugated radio-sensitizer (Methotrexate) loaded block copolymeric micelles with Indium-111. The indium-111 emitted radionuclides in the peri-nuclear as well as nuclear areas in breast cancer cells (73).

5. NK012 is a polymeric micelle of block copolymer PEG-Polyglutamate conjugated with 7-ethyl-10-hydroxyCampothecin (SN-38) (74). It has completed phase II clinical trials for triple-negative breast cancer and relapsed small cell lung cancer (75).
In 2016, Nippon Kayaku received orphan drug designation for NK012 from the US FDA (76).

\section{Conclusions}

In order to achieve better bioavailability and minimized negative effects, new pharmaceutical forms with controlled or targeted release have been developed. Nanoparticles represent a large part of these pharmaceutical formulations, that are currently involved in breast cancer treatment.

Nanoparticle systems such as liposomes, dendrimers, polymeric micelles and inorganic nanoparticles are under both preclinical and clinical trials for breast cancer.

In this review article, several examples of anticancer agents loaded polymeric micelles were mentioned, illustrating the preparation methods and the current state of clinical studies in which polymeric micelles are used. The micellar formulations must comply with the current Pharmacopoeias and the Good Manufacturing Process conditions. Clinical studies require team work between researchers and clinicians, for a multidisciplinary expertise.

Until 2018, sevaral targeted micelle formulations have been investigated in breast cancer clinical trials: Genexol-PM, Nanoxel, NK012 and NK105.(56) 


\section{Conflict of interest}

\section{The authors declare no conflict of interest.}

\section{References}

1. Ganz PA, Goodwin PJ. Breast Cancer Survivorship: Where Are We Today? Advances in experimental medicine and biology. 2015;862:1-8. https://doi.org/10.1007/978-3-319-16366-6 1

2. Network CBC. Sub-Types of Breast Cancer [Available from: https://cbcn.ca/en/subtypes of breast cancer].

3. Kimmick GG, Muss HB. Endocrine therapy in metastatic breast cancer. Cancer treatment and research.1998;94:231-54. https://doi.org/10.1007/978-1-4615-6189-7 13

4. Nagini S. Breast Cancer: Current Molecular Therapeutic Targets and New Players. Anti-cancer agents in medicinal chemistry. 2017;17(2):152-63. https://doi.org/10.2174/1871520616666160502122724

5. Parkin DM, Bray F, Ferlay J, Pisani P. Global cancer statistics, 2002. CA: a cancer journal for clinicians. 2005;55(2):74-108.

https://doi.org/10.3322/canjclin.55.2.74

6. Jemal A, Siegel R, Ward E, Hao Y, Xu J, Thun MJ. Cancer statistics, 2009. CA: a cancer journal for clinicians.2009;59(4):225-49.

https://doi.org/10.3322/caac.20006

7. Haber G, Ahmed NU, Pekovic V. Family history of cancer and its association with breast cancer risk perception and repeat mammography. American journal of public health. 2012;102(12):2322-9. https://doi.org/10.2105/AJPH.2012.300786

8. Unlu O, Kiyak D, Caka C, Yagmur M, Yavas HG, Erdogan $\mathrm{F}$, et al. Risk factors and histopathological features of breast cancer among women with different menopausal status and age at diagnosis. Journal of BUON : official journal of the Balkan Union of Oncology. 2017;22(1):184-91.

9. Picon-Ruiz M, Morata-Tarifa C, Valle-Goffin JJ, Friedman ER, Slingerland JM. Obesity and adverse breast cancer risk and outcome: Mechanistic insights and strategies for intervention. CA: a cancer journal for clinicians.2017;67(5):378-97. https://doi.org/10.3322/caac.21405

10. Chajes V, Romieu I. Nutrition and breast cancer. Maturitas.2014;77(1):7-11. https://doi.org/10.1016/i.maturitas.2013.10.004
11. Lahart IM, Metsios GS, Nevill AM, Carmichael AR. Physical activity, risk of death and recurrence in breast cancer survivors: A systematic review and metaanalysis of epidemiological studies. Acta oncologica. 2015;54(5):635-54.

https://doi.org/10.3109/0284186X.2014.998275

12. LaBarge MA, Mora-Blanco EL, Samson S, Miyano M. Breast Cancer beyond the Age of Mutation. Gerontology.2016;62(4):434-42. https://doi.org/10.1159/000441030

13. Brinton LA, Brogan DR, Coates RJ, Swanson CA, Potischman N, Stanford JL. Breast cancer risk among women under 55 years of age by joint effects of usage of oral contraceptives and hormone replacement therapy. Menopause. 2018;25(11):1195-200. https://doi.org/10.1097/GME.0000000000001217

14. Boyages J. Radiation therapy and early breast cancer: current controversies. The Medical journal of Australia. 2017;207(5):216-22. https://doi.org/10.5694/mja16.01020

15. Dumitrescu RG, Cotarla I. Understanding breast cancer risk -- where do we stand in 2005? Journal of cellular and molecular medicine. 2005;9(1):208-21. https://doi.org/10.1111//.1582-4934.2005.tb00350.x

16. Gancberg D, Lespagnard L, Rouas G, Paesmans M, Piccart M, Di Leo A, et al. Sensitivity of HER-2/neu antibodies in archival tissue samples of invasive breast carcinomas. Correlation with oncogene amplification in 160 cases. American journal of clinical pathology. 2000;113(5):675-82.

https://doi.org/10.1309/0F58-0GRX-FK4R-A6VA

17. Sinn HP, Kreipe H. A Brief Overview of the WHO Classification of Breast Tumors, 4th Edition, Focusing on Issues and Updates from the 3rd Edition. Breast care.2013;8(2):149-54. https://doi.org/10.1159/000350774

18. Dai X, Li T, Bai Z, Yang Y, Liu X, Zhan J, et al. Breast cancer intrinsic subtype classification, clinical use and future trends. American journal of cancer research. 2015;5(10):2929-43. https://doi.org/10.1371/journal.pone.0124964

19. Cedolini C, Bertozzi S, Londero AP, Bernardi S, Seriau L, Concina S, et al. Type of breast cancer diagnosis, screening, and survival. Clinical breast cancer. 2014;14(4):235-40. https://doi.org/10.1016/i.clbc.2014.02.004

20. Blasiak B, van Veggel FC, Tomanek B. Applications of nanoparticles for MRI cancer diagnosis and therapy. Journal of Nanomaterials. 2013;2013:12. https://doi.org/10.1155/2013/148578 
21. Han YHCH-K. Nanomedicines: current status and future perspectives in aspect of drug delivery and pharmacokinetics 2018 [Available from: https://link.springer.com/article/10.1007\%2Fs40005017-0370-4].

22. Ani-Simona Sevastre FP, Anca Berbecaru, O. Croitoru, Mihaela Baniceru. Pharmacokinetic evaluation after percutaneous administration of some non $\square$ steroidal antiinflamatory drug preparations using animal experiments 2009 [Available from: http://www.terapeutica.ro/img/art/pdf/383/8.OP7.pdf].

23. Sevastre A-S, Cazacincu R, Lupuleasa D, Belu I, Popescu F. Influence of some dis-solution enhancing agents on the pharmacokinetic profile of meloxicam delivered from hydrophilic ointments 2010 [Available from:

https://www.chsjournal.org/CHSJ/papers/CHSJ.36.03. 09.pdf].

24. Soares S, Sousa J, Pais A, Vitorino C. Nanomedicine: Principles, Properties, and Regulatory Issues. Frontiers in chemistry. 2018;6:360. https://doi.org/10.3389/fchem.2018.00360

25. Opacic T, Paefgen V, Lammers T, Kiessling F. Status and trends in the development of clinical diagnostic agents. Wiley interdisciplinary reviews Nanomedicine and nanobiotechnology. 2017;9(4). https://doi.org/10.1002/wnan.1441

26. Bobo D, Robinson KJ, Islam J, Thurecht KJ, Corrie SR. Nanoparticle-Based Medicines: A Review of FDAApproved Materials and Clinical Trials to Date. Pharm Res.2016;33(10):2373-2387. https://doi.org/10.1007/s11095-016-1958-5

27. Siegrist S, Corek E, Detampel P, Sandstrom J, Wick P, Huwyler J. Preclinical hazard evaluation strategy for nanomedicines. Nanotoxicology. 2018:1-27. https://doi.org/10.1080/17435390.2018.1505000

28. Nounou MI, ElAmrawy F, Ahmed N, Abdelraouf K, Goda S, Syed-Sha-Qhattal H. Breast Cancer: Conventional Diagnosis and Treatment Modalities and Recent Patents and Technologies. Breast cancer : basic and clinical research. 2015;9(Suppl 2):17-34. https://doi.org/10.4137/BCBCR.S29420

29. Alexandru O, Dragutescu L, Tataranu L, Ciubotaru V, Sevastre A, Georgescu AM, et al. Helianthin induces antiproliferative effect on human glioblastoma cells in vitro. J Neurooncol. 2011;102(1):9-18. https://doi.org/10.1007/s11060-010-0285-7

30. Harbeck N, Gnant M. Breast cancer. Lancet. 2017;389(10074):1134-50.

https://doi.org/10.1016/S0140-6736(16)31891-8
31. Dhankhar R, Vyas SP, Jain AK, Arora S, Rath G, Goyal AK. Advances in novel drug delivery strategies for breast cancer therapy. Artificial cells, blood substitutes, and immobilization biotechnology. 2010;38(5):230-49.

https://doi.org/10.3109/10731199.2010.494578

32. Goldhirsch A, Winer EP, Coates AS, Gelber RD, Piccart-Gebhart M, Thurlimann B, et al. Personalizing the treatment of women with early breast cancer: highlights of the St Gallen International Expert Consensus on the Primary Therapy of Early Breast Cancer 2013. Annals of oncology : official journal of the European Society for Medical Oncology. 2013;24(9):2206-23. https://doi.org/10.1093/annonc/mdt303

33. Li F, Jiang T, Li Q, Ling X. Camptothecin (CPT) and its derivatives are known to target topoisomerase I (Top1) as their mechanism of action: did we miss something in CPT analogue molecular targets for treating human disease such as cancer? Am J Cancer Res. 2017;7(12):2350-94.

34. Alexandru O, Ciubotaru V, Tataranu L, Fetea S, Badea $P$, Dricu A. The relationship between cognitive function, tumour histology and surgical treatment in patients with primary brain tumours. Journal of Neurology; 2008;255:154-154.

35. Dricu A, Catrina S-B, Brismar K, Biberfeld P, Andersson LC. A synthetic peptide derived from the human eosinophil-derived neurotoxin induces apoptosis in Kaposi's sarcoma cells. Anticancer research. 2004;24(3A):1427-32.

36. Nogueira DR, Tavano L, Mitjans M, Perez L, Infante $M R$, Vinardell MP. In vitro antitumor activity of methotrexate via $\mathrm{pH}$-sensitive chitosan nanoparticles. Biomaterials. 2013; 34(11):2758-72. https://doi.org/10.1016/i.biomaterials.2013.01.005

37. Beyzay F, Zavaran Hosseini A, Soudi S. Alpha Alumina Nanoparticle Conjugation to Cysteine Peptidase A and B: An Efficient Method for Autophagy Induction. Avicenna J Med Biotechnol. 2017 AprJun;9(2):71-81

38. Chen WY WT, inventor Bi-functional cancer treatment agents 2007.

39. Sanchez C GM, Wright S, et al., , inventor Phytocannabinoids for use in the treatment of breast cancer 2014.

40. Slade M CR, inventor; Martin Slade and Raoul Charles Coombes, assignee. Breast cancer methods, medicaments and agents 2010. 
41. Njar VCO GL, Khandelwal A, inventor; University of Maryland, Baltimore, assignee. Novel retinamide retinoic acid metabolism blocking agents2010.

42. Nakamura Y KT, Nakatsuru S, inventor; Oncotherapy Science, Inc, assignee. Genes and polypeptides relating to breast cancers2014.

43. Brigger I, Dubernet C, Couvreur P. Nanoparticles in cancer therapy and diagnosis. Advanced drug delivery reviews.2002;54(5):631-51.

https://doi.org/10.1016/S0169-409X(02)00044-3

44. Singh SK, Singh S, Lillard JW, Jr., Singh R. Drug delivery approaches for breast cancer. International journal of nanomedicine. 2017;12:6205-18. https://doi.org/10.2147/IJN.S140325

45. Bazile D, Prud'homme C, Bassoullet MT, Marlard M, Spenlehauer G, Veillard M. Stealth Me.PEG-PLA nanoparticles avoid uptake by the mononuclear phagocytes system. Journal of pharmaceutical sciences.1995;84(4):493-8.

https://doi.org/10.1002/jps.2600840420

46. Weissenbock A, Wirth M, Gabor F. WGA-grafted PLGA-nanospheres: preparation and association with Caco-2 single cells. Journal of controlled release : official journal of the Controlled Release Society. 2004;99(3):383-92.

https://doi.org/10.1016/j.jconrel.2004.07.025

47. Wesselinova D. Current major cancer targets for nanoparticle systems. Current cancer drug targets. 2011;11(2):164-83.

https://doi.org/10.2174/156800911794328484

48. Bhatia S. Natural polymer drug delivery systems: Springer;2016.

https://doi.org/10.1007/978-3-319-41129-3

49. Biswas S, Kumari P, Lakhani PM, Ghosh B. Recent advances in polymeric micelles for anti-cancer drug delivery. European journal of pharmaceutical sciences : official journal of the European Federation for Pharmaceutical Sciences. 2016;83:184-202. https://doi.org/10.1016/j.ejps.2015.12.031

50. Liu Q, Zhang J, Sun W, Xie QR, Xia W, Gu H. Delivering hydrophilic and hydrophobic chemotherapeutics simultaneously by magnetic mesoporous silica nanoparticles to inhibit cancer cells. International journal of nanomedicine. 2012;7:9991013.

https://doi.org/10.2147//JN.S28088

51. Aliabadi HM, Elhasi S, Mahmud A, Gulamhusein R, Mahdipoor P, Lavasanifar A. Encapsulation of hydrophobic drugs in polymeric micelles through cosolvent evaporation: the effect of solvent composition on micellar properties and drug loading. International journal of pharmaceutics. 2007;329(1-2):158-65. https://doi.org/10.1016/j.ijpharm.2006.08.018

52. Kulthe SS, Choudhari YM, Inamdar NN, Mourya V. Polymeric micelles: authoritative aspects for drug delivery. Designed Monomers and Polymers. 2012;15(5):465-521.

https://doi.org/10.1080/1385772X.2012.688328

53. Alvarez-Lorenzo C, Concheiro A. Intelligent drug delivery systems: polymeric micelles and hydrogels. Mini reviews in medicinal chemistry. 2008;8(11):106574.

https://doi.org/10.2174/138955708785909952

54. Zhang Y, Huang Y, Li S. Polymeric micelles: nanocarriers for cancer-targeted drug delivery. AAPS PharmSciTech.2014;15(4):862-71. https://doi.org/10.1208/s12249-014-0113-z

55. Oerlemans C, Bult W, Bos M, Storm G, Nijsen JF, Hennink WE. Polymeric micelles in anticancer therapy: targeting, imaging and triggered release. Pharmaceutical research. 2010;27(12):2569-89. https://doi.org/10.1007/s11095-010-0233-4

56. Cho H, Lai TC, Tomoda K, Kwon GS. Polymeric micelles for multi-drug delivery in cancer. AAPS PharmSciTech.2015;16(1):10-20. https://doi.org/10.1208/s12249-014-0251-3

57. Hanafy NAN, El-Kemary M, Leporatti S. Micelles Structure Development as a Strategy to Improve Smart Cancer Therapy. Cancers. 2018;10(7). https://doi.org/10.3390/cancers 10070238

58. Peng $X$, Zhang L. Formation and morphologies of novel self-assembled micelles from chitosan derivatives. Langmuir : the ACS journal of surfaces and colloids. 2007;23(21):10493-8. https://doi.org/10.1021/la701325v

59. Fang J. Enhanced permeability and retention effect based nanomedicine, a solution for cancer. World Journal of Pharmacology. 2015;4(2):168-71. https://doi.org/10.5497/wjp.v4.i2.168

60. Yuan Y, Cai T, Xia X, Zhang R, Chiba P, Cai Y. Nanoparticle delivery of anticancer drugs overcomes multidrug resistance in breast cancer. Drug delivery. 2016;23(9):3350-7. https://doi.org/10.1080/10717544.2016.1178825

61. Torchilin VP. Targeted polymeric micelles for delivery of poorly soluble drugs. Cellular and molecular life sciences : CMLS. 2004;61(19-20):2549-59. https://doi.org/10.1007/s00018-004-4153-5

62. Seo DH, Jeong YI, Kim DG, Jang MJ, Jang MK, Nah JW. Methotrexate-incorporated polymeric nanoparticles of methoxy poly(ethylene glycol)-grafted chitosan. Colloids and surfaces B, Biointerfaces. 
2009;69(2):157-63.

https://doi.org/10.1016/j.colsurfb.2008.10.020

63. Gong J, Chen M, Zheng Y, Wang S, Wang Y. Polymeric micelles drug delivery system in oncology. Journal of controlled release : official journal of the Controlled Release Society. 2012;159(3):312-23. https://doi.org/10.1016/i.jconrel.2011.12.012

64. Ranade A, Joshi D, Phadke G, Patil P, Kasbekar R, Apte $\mathrm{T}$, et al. Clinical and economic implications of the use of nanoparticle paclitaxel (Nanoxel) in India. Annals of oncology. 2013;24(suppl_5):v6-v12. https://doi.org/10.1093/annonc/mdt322

65. Lee KS, Chung HC, Im SA, Park YH, Kim CS, Kim SB, et al. Multicenter phase II trial of Genexol-PM, a Cremophor-free, polymeric micelle formulation of paclitaxel, in patients with metastatic breast cancer. Breast cancer research and treatment. 2008;108(2):241-50. https://doi.org/10.1007/s10549-007-9591-y

66. Verhoeven DT, Verhagen $\mathrm{H}$, Goldbohm RA, van den Brandt PA, van Poppel G. A review of mechanisms underlying anticarcinogenicity by brassica vegetables. Chem Biol Interact. 1997;103(2):79-129. https://doi.org/10.1016/S0009-2797(96)03745-3

67. Xiong MP, Yanez JA, Remsberg CM, Ohgami Y, Kwon GS, Davies NM, et al. Formulation of a geldanamycin prodrug in mPEG-b-PCL micelles greatly enhances tolerability and pharmacokinetics in rats. Journal of controlled release : official journal of the Controlled Release Society. 2008;129(1):33-40. https://doi.org/10.1016/i.jconrel.2008.03.015

68. Kim T, Gwak G, Chung M, Kim J, Park I, Um E, et al. $11 \mathrm{P}$ Multicenter trial for safety and toxicity of a nanoparticle docetaxel formulation in breast cancer. Annals of Oncology. 2018;29(suppl_9):mdy426. 010. https://doi.org/10.1093/annonc/mdy426.010
69. Alexandru O, Dragutescu L, Tataranu L, Ciubotaru V, Sevastre A, Georgescu AM, et al. Helianthin induces antiproliferative effect on human glioblastoma cells in vitro. Journal of neuro-oncology. 2011;102(1):9-18. https://doi.org/10.1007/s11060-010-0285-7

70. Lee AL, Wang Y, Cheng HY, Pervaiz S, Yang YY. The co-delivery of paclitaxel and Herceptin using cationic micellar nanoparticles. Biomaterials. 2009;30(5):91927. https://doi.org/10.1016/j.biomaterials.2008.10.062

71. Sadat SM, Saeidnia S, Nazarali AJ, Haddadi A. Nanopharmaceutical formulations for targeted drug delivery against HER2 in breast cancer. Current cancer drug targets. 2015;15(1):71-86. https://doi.org/10.2174/1568009615666150105115047

72. Zhao J, Mi Y, Feng SS. Targeted co-delivery of docetaxel and siPlk1 by herceptin-conjugated vitamin E TPGS based immunomicelles. Biomaterials. 2013;34(13):3411-21.

https://doi.org/10.1016/j.biomaterials.2013.01.009

73. Hoang B, Reilly RM, Allen C. Block copolymer micelles target Auger electron radiotherapy to the nucleus of HER2-positive breast cancer cells. Biomacromolecules.2012;13(2):455-65. https://doi.org/10.1021/bm201479t

74. Matsumura Y, Kataoka K. Preclinical and clinical studies of anticancer agent-incorporating polymer micelles. Cancer science. 2009;100(4):572-9. https://doi.org/10.1111/j.1349-7006.2009.01103.x

75. NK012 Phase II clinical trials for triple-negative breast cancer and relapsed small cell lung cancer [Available from:

https://clinicaltrials.gov/ct2/results?term=NK012]

76. Orphan drug designation for NK012 [Available from:https://www.nipponkayaku.co.jp/english/ir/busines s/files/pharmaceuticals.pdf]. 